\title{
Development and Validation of Chromatographic Methods for Simultaneous Determination of Ibuprofen and Famotidine in Presence of Related Substances in Pharmaceutical Formulations
}

\author{
Eman S. Elzanfaly, Hala E. Zaazaa, Aya T. Soudi* \\ and Maissa Y. Salem \\ Analytical Chemistry Department, Faculty of Pharmacy, Cairo University, Kasr El-Aini Street, Cairo 11562, Egypt \\ *Corresponding author: E-mail: ayoosh_soudi@yahoo.com \\ Telephone: 00237753303 \\ Received: 04-06-2014
}

\begin{abstract}
Two validated methods for the simultaneous determination of ibuprofen and famotidine in the presence of ibuprofen impurity (4-isobutylacetophenone) and/or famotidine degradation products were described. The first method was a simple TLC method where separation was performed on silica gel plates using ethyl acetate: methanol: ammonia (9:2:1, by volume) as a mobile phase. $R_{\mathrm{f}}$ values were found to be $0.40,0.94,0.66,0.27,0.83$ for ibuprofen, 4-isobutylacetophenone, famotidine, famotidine acid and basic degradation products, respectively. The second method was HPLC on C18 column using methanol: phosphate buffer $\mathrm{pH} 3(80: 20, \mathrm{v} / \mathrm{v})$ as a mobile phase. Retention times were found to be $2.2 \mathrm{~min}$, $9.9 \mathrm{~min}$, and $8.6 \mathrm{~min}$ for famotidine, ibuprofen, and 4-isobutylacetophenone, respectively. Both methods were validated according to the ICH guidelines and applied for the determination of the two drugs in pure powder and combined dosage form without interference from the excipients.
\end{abstract}

Keywords: Ibuprofen, Famotidine, Degradation products and impurities, TLC-densitometry and HPLC

\section{Introduction}

Ibuprofen (IBU) (Figure 1a) is chemically $\alpha$ methyl-4-(2-methylpropyl) benzene acetic acid, 2-(p-Isobutyl phenyl) propanoic acid, 4-Isobutylhydratropic acid. ${ }^{1}$ It is a non-steroidal anti- inflammatory drug (NSAIDS) which inhibits prostaglandin synthesis by blocking the enzyme cyclooxygenase (COX enzyme) that converts arachidonic acid into prostaglandin. ${ }^{2}$

Famotidine (FAM) (Figure 2a) is chemically $3-[(\{2-$ [(diaminomethylidene)amino]-1,3-thiazol-4-yl\}methyl) sulfanyl]- $N$ '-sulfamoylpropanimidamide. It is used to block the action of histamine on the stomach cells, so decrease the production of acid by the stomach. ${ }^{2}$ IBU and FAM are co-formulated in a mixture form used for the treatment of rheumatoid arthritis where FAM reduces the gastrointestinal toxicity of IBU. ${ }^{2}$

The literature review reveals that IBU and FAM we- re determined in combination by spectrophotometry, ${ }^{1-4}$ HPLC, ${ }^{5-10}$ and TLC. ${ }^{11}$

Various regulatory authorities like USFDA, Canadian Drug and Health Agency are emphasizing on the purity requirements and the identification of impurities in Active Pharmaceutical Ingredients (APIs). The impurity may be developed either during formulation, or upon aging of either APIs or formulation. Thus development of an analytical method of analysis for the API in the presence of related impurities and degradation products is very important in the pharmaceutical industry. All the reported methods did not determine IBU or FAM in their combination in presence of either impurities or degradation products of both drugs. So, the aim of this work was to develop and validate quantitative and more selective methods for the determination of IBU and FAM in their combined dosage form and in the presence of acid and basic degradation products of famotidine 
<smiles>CC(C)Cc1ccc(C(C)C(=O)O)cc1</smiles>

Figure 1a: Ibuprofen

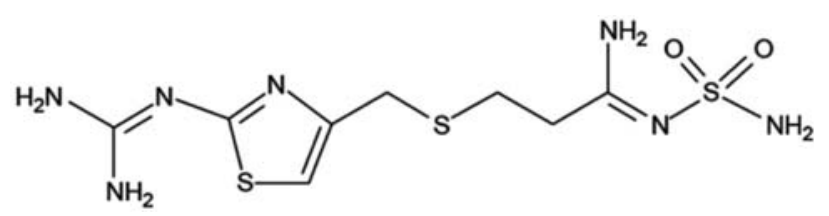

Figure 2a: Famotidine

and IBU impurity (4-isobutylacetophenone) by TLCdensitometric method and high performance liquid chromatography.

\section{Experimental}

\section{1. Instruments}

- Pre-coated silica gel TLC aluminum plates F254; $20 \times$ $20 \mathrm{~cm}$; layer thickness, $0.25 \mathrm{~mm}$, Fluka (Buchs, Switzerland), a CAMAG Linomat 5, autosampler (Muttens, Switzerland) with a constant application rate $10 \mu \mathrm{l} \mathrm{s}^{-1}$ were used. Densitometric scanning was performed on a CAMAG TLC densitometric Scanner 3S/N 130319 in the reflectance absorbance mode at $265 \mathrm{~nm}$ for all measurements and operated by WINCATS software (Muttens, Switzerland).

- An HPLC system that consists of Agilent 1100series control module by Agilent chemstation for HPLC equipped with a quaternary pump, injector with a $20 \mu \mathrm{l}$ loop and a UV-variable wavelength detector (Minnesota, USA) were used. Separation was done on an Intersil ODS-3 C 18 RP column $(250 \times 4.6 \mathrm{~mm}, 5 \mu \mathrm{m}$ particle size).

\section{2. Materials and Reagents}

\section{2. 1. Pure Standard}

Ibuprofen working standard and 4-isobutylacetophenone were obtained as a kind gift sample from Kahira Company, Cairo, Egypt. The purity of IBU was reported to be $99.8 \%$. FAM working standard was obtained as kind gift sample from Amoun Company, Cairo, Egypt, and its purity was reported to be $99.9 \%$.

\section{2. 2. Pharmaceutical Formulation}

Duexis® tablets (Duexis ${ }^{\circledR}$, Batch No. 8064869, label claim: $800 \mathrm{mg}$ IBU and $26.6 \mathrm{mg}$ FAM manufactured by Horizon Pharma, USA were purchased from the local market.

\section{2. 3. Chemicals and Reagents}

Methanol (HPLC grade), isopropanol and ethyl acetate were obtained from Sigma Aldrich, Cairo, Egypt. Ammonia solution 33\%, sodium hydroxide and concentrated hydrochloric acid were obtained from Adwic, Cairo, Egypt.

\section{2. 4. Preparation of Acid and Basic Degradation Products of Famotidine}

For acid degradation, FAM was dissolved in $1 \mathrm{~N}$ $\mathrm{HCl}$, refluxed in a $250-\mathrm{mL}$ round-bottom flask for $30 \mathrm{~min}$. The acidic solution was then evaporated and the obtained residue was then dissolved in methanol.

For basic degradation, ${ }^{12}$ FAM was dissolved in $1 \mathrm{~N}$ $\mathrm{NaOH}$, refluxed in a 250-mL round-bottom flask for $1 \mathrm{~h}$. The basic solution was cooled and left over night in the refrigerator at $8{ }^{\circ} \mathrm{C}$, and then the formed brown shiny crystals were separated, washed with water $(10 \mathrm{~mL})$ and then dissolved in methanol.

\section{3. Standard Solutions}

For the TLC method; Stock solutions of $5 \mathrm{mg} \mathrm{mL}^{-1}$ IBU, $1 \mathrm{mg} \mathrm{mL}^{-1}$ FAM and $1 \mathrm{mg} \mathrm{mL}^{-1} 4$-isobutylacetophenone were prepared in methanol. Stock solutions in methanol of acid and basic degradation products of FAM derived from complete degradation of $1 \mathrm{mg} \mathrm{mL}^{-1}$ of FAM.

For the HPLC method; Stock solutions of $2 \mathrm{mg}$ $\mathrm{mL}^{-1}$ IBU, $1 \mathrm{mg} \mathrm{mL}^{-1}$ FAM and $1 \mathrm{mg} \mathrm{mL}^{-1} 4$-isobutylacetophenone were prepared separately in the mobile phase. Stock solutions in mobile phase of acid and basic degradation products of FAM derived from complete degradation of $1 \mathrm{mg} \mathrm{mL}^{-1}$ of FAM.

All stock standard solutions were freshly prepared on the day of analysis.

\section{4. Laboratory Prepared Mixtures}

Solutions containing different ratios of IBU, FAM, 4-isobutylacetophenone and / or acid and basic degradation products were prepared.

\section{5. Procedure}

\section{5. 1. Construction of Calibration Curve TLC-densitometric Method}

Into a series of $10-\mathrm{mL}$ volumetric flasks, aliquots equivalent to 5-30 mg IBU and 0.3-1.3 mg FAM were accurately transferred from their respective standard stock solution, and then the volume was completed with methanol. $10 \mu \mathrm{L}$ of each solution was separately applied in triplicates as bands onto TLC plates (bandwidth: $6 \mathrm{~mm}$; spacing: 14.2 $\mathrm{mm} ; 15 \mathrm{~mm}$ from bottom edge of the plate) using a Camag applicator. Linear ascending development was done in a chromatographic tank previously saturated with the develo- 
ping system consists of ethyl acetate: methanol: ammonia (9:2:1, by volume) at room temperature. The developed plates were air dried and scanned at $265 \mathrm{~nm}$. A calibration curve was constructed by plotting peak areas against the corresponding concentrations of each drug.

\section{RP-HPLC Method}

Aliquots equivalent to $480-1120 \mu \mathrm{g}$ IBU, $16-37 \mu \mathrm{g}$ FAM were transferred from their corresponding stock solutions into a series of $10 \mathrm{~mL}$ volumetric flasks. The volume was then completed with mobile phase. The chromatographic separation was carried out on reversed phase Intersil ODS- 3 column [ $\mathrm{C}_{18}(5$ micron, $4.6 \times 250 \mathrm{~mm})$ ], using methanol: phosphate buffer $\mathrm{pH} 3(80: 20$, v/v) as a mobile phase. The mobile phase was filtered through Millipore filter $0.45 \mu \mathrm{m}$, white nylon HNWP $47 \mathrm{~mm}$ and was degassed for $15 \mathrm{~min}$ in an ultrasonic bath prior to use. UV detection was done at $265 \mathrm{~nm}$. The system was operated at ambient temperature. The flow rate was isocratic at $1 \mathrm{~m}$ $\mathrm{L} / \mathrm{min}$. The samples were filtered through a $0.45 \mu \mathrm{m} \mathrm{mem-}$ brane filter, and $20 \mu \mathrm{L}$ were injected by the aid of an Agilent ${ }^{\circledR}$ analytical syringe. The chromatograms were recorded, the peak areas of each drug were determined and the calibration curves relating peak areas to the corresponding concentrations for IBU and FAM were constructed.

\section{5. 2. Application on the Pharmaceutical Formulation}

Ten tablets of Duexis ${ }^{\circledR}$ tablets were weighed and powdered. An accurately weighed amount of the powder equivalent to $800 \mathrm{mg}$ IBU and $26.6 \mathrm{mg}$ FAM were transferred into $100-\mathrm{mL}$ volumetric flasks, $50 \mathrm{~mL}$ of methanol was added as a solvent and sonicated for $30 \mathrm{~min}$. The volume was completed to the mark, and then filtered. The procedure for each method was completed as mentioned above.

\section{Results and Discussion}

This paper reports development and validation of two chromatographic methods for the quantitative determination of IBU and FAM in their combined dosage form and in the presence of IBU impurity; 4-isobutylacetophenone and /or acid and basic degradation products of famotidine by TLC -densitometric method and high performance liquid chromatography.

4- isobutylacetophenone (Figure $1 b$ ) is mentioned in the British Pharmacopeia to be a photo-degradation impurity for IBU. It is also mentioned in the USP Pharmacopeia to be a related substance in IBU tablets. This compound is reported to cause adverse effects in the central nervous system.

Comprehensive stress testing of FAM was carried out according to the International Conference on Harmo-

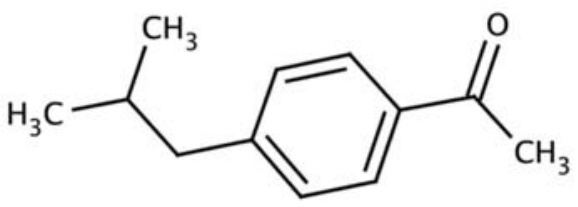

Figure 1b: Ibuprofen impurity (4-isobutylacetophenone)

nization (ICH) guideline Q1A (R2), ${ }^{14}$ where the drug was subjected to acid and basic hydrolysis and oxidation to conduct forced degradation studies. The drug was stable against oxidation with $30 \% \mathrm{H}_{2} \mathrm{O}_{2}$, while in acid solution using $1 \mathrm{~N} \mathrm{HCl}$ the drug hydrolyzed into a new compound which was proved by IR and Mass spectroscopy to be $N$ (aminosulphonyl)-3-[[[2-[(diaminomethylene)amino]thiazol-4-1]methyl]thio]propanamide (Figure 2b). This compound is mentioned to be an impurity for FAM. ${ }^{15}$ While treatment of FAM with $1 \mathrm{~N} \mathrm{NaOH}$, results in production of brown shiny crystals which were identified by Sing et al. ${ }^{12}$ (Figure 2c)

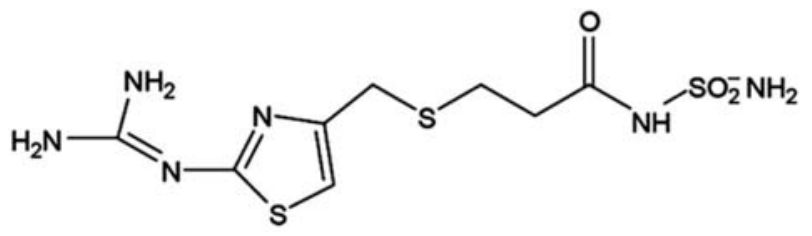

Figure 2b: Famotidine acid degradate (impurity C)

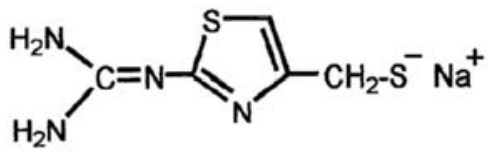

Figure 2c: Famotidine base degradate (Brown shiny crystals)

\section{1. Methods Optimization}

\section{TLC- densitometric method}

TLC procedure was optimized to develop a stability indicating assay method for quantification of IBU and FAM. Different mobile phases were tried to improve the separation of pure drugs, degradation products and impurities. Initially methanol was used as mobile phase but no separation was obtained. Increasing the polarity by addition of water did not enhance the separation between IBU and acid degradation product of FAM, while addition of ammonia solution caused tailing of IBU band. Finally; sharp and symmetric peaks were obtained by using ethyl acetate: methanol: ammonia (9:2:1 by volume) where good separation was obtained between the binary mixture, degradation products and impurities with good $R_{f}$ values without tailing of the separated bands (Figure 3). The op- 
timum band width was $6 \mathrm{~mm}$ and the inter-space between bands was $14.2 \mathrm{~mm}$. Detection at $265 \mathrm{~nm}$ was suitable providing good sensitivity for IBU and FAM with minimum noise. Slit dimensions of the scanning light beam should ensure complete coverage of band dimensions on the scanned track without interference of adjacent bands. $5 \mathrm{~mm} \times 0.2 \mathrm{~mm}$ proved to be the slit dimension of choice which provides highest sensitivity.

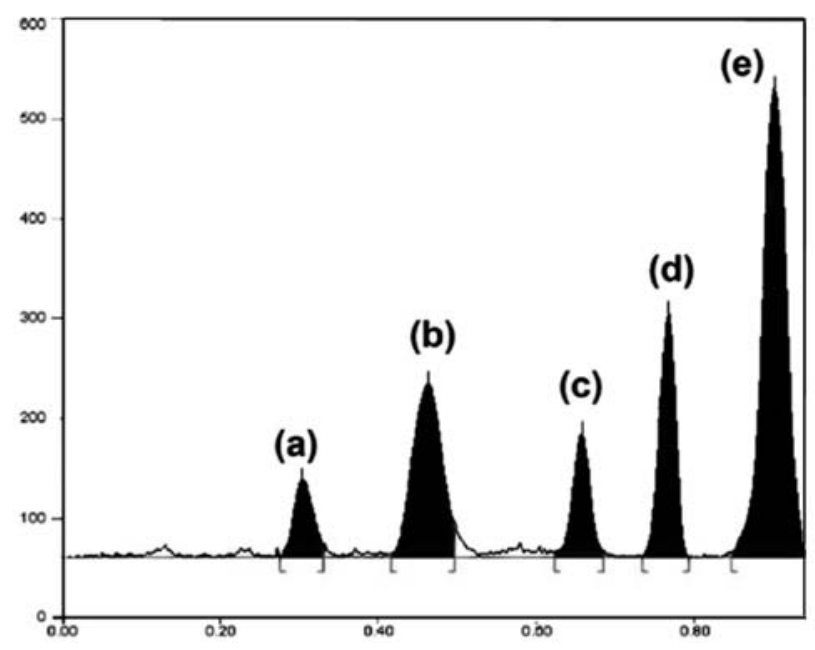

Figure 3: Separation of drugs from degradates and impurities with different Rf values (a) FAM acidic degradate $0.34 \mathrm{Rf}$ (b) Ibuprofen $0.49 \mathrm{Rf}$ (c) famotidine 0.67 Rf (d) FAM basic degradate 0.76 Rf (e) Ibuprofen impurity

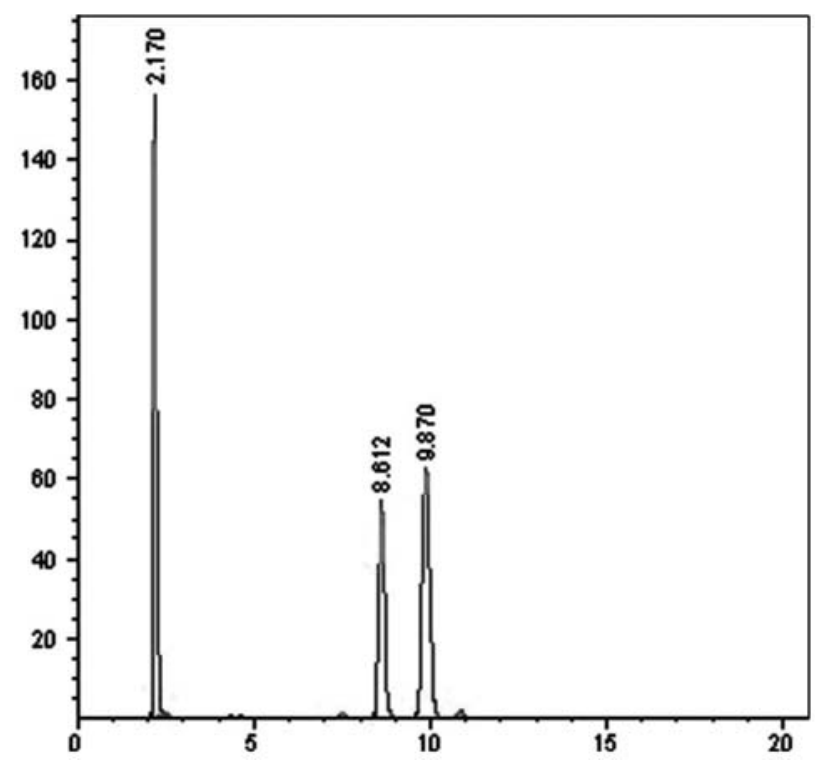

Figure 4. HPLC chromatogram of a mixture of famotidine (Rt 2.17 $\mathrm{min}$ ), Ibuprofen (Rt 9.87 $\mathrm{min}$ ) and ibuprofen impurity (Rt $8.61 \mathrm{~min}$ )

\section{RP-HPLC Method}

Different developing systems of different composition were tried for separation. The initial separation was developed using ethanol: water (50:50) as a green solvent but poor symmetric peaks were observed. By decreasing the $\mathrm{pH}$ to 4.5 using acetic acid, IBU was retained on column; while increasing the $\mathrm{pH}$ to 9.2 using triethanol amine $0.5 \%$ the peaks separated but poor peak symmetry occurs. Finally; the use of methanol: phosphate buffer $\mathrm{pH} 3$ $(80: 20, \mathrm{v} / \mathrm{v})$ as a mobile phase gave satisfactory separation and peak symmetry. Best separation was obtained on a $\mathrm{C}_{18}$ RP column $(250 \times 4.6 \mathrm{~mm}, 5 \mu \mathrm{m}$ particle size $)$ with flow rate of $1 \mathrm{ml} \mathrm{min}{ }^{-1}$. Maximum sensitivity was obtained at $265 \mathrm{~nm}$.

A satisfactory separation obtained using the optimum conditions, where the retention time $(\mathrm{Rt})$ values of IBU was $9.87 \mathrm{~min}$ while for FAM $2.17 \mathrm{~min}$ and for IBU impurity was 8.61 min.(Figure 4 )

\section{2. Methods Validation}

The suggested procedures were subjected to the validation scheme according to $\mathrm{ICH}$ guidelines, ${ }^{16}$ where good results were obtained, Table 1.

Linear relationships were obtained by plotting concentrations of the IBU and FAM against corresponding peak areas, Table 1.

The accuracy of the investigated methods was also evaluated by applying the standard addition technique (Table 2\&3).

Specificity was ascertained by analysing different mixtures containing IBU, FAM and its degradation products or impurities. Satisfactory results were obtained indicating the high selectivity of the proposed methods (Table 1).

Robustness of the methods was also checked by investigating the effect of small deliberate changes in the experimental conditions on the system suitability parameters. Mixtures of IBU, FAMand IBU impurity were separated under different conditions by using different $\mathrm{pH}$ values $3.0 \pm 0.2$, different flow rates $(1.0 \pm$ $0.2 \mathrm{~mL} \mathrm{~min}^{-1}$ ) and different methanol composition by $80 \pm 5 \%$ as the mobile phase. The Rt values of the separated peaks using the mentioned $\mathrm{pH}$ range did not change, while changing the flow rate and mobile phase was accompanied by slight decrease or increase of Rt of all peaks. However, the calculated resolution $(\mathrm{R})$ values were always above 2 , ensuring complete separation.Other parameters such as resolution, capacity factor and selectivity for the separated peaks were shown in Tables 4 and 5.

The suggested methods were successfully applied for determination of IBU and FAM in their pharmaceutical formulation (Duexis ${ }^{\circledR}$ tablets). The results were satisfactory and with good agreement with the labeled amounts. Applying the standard addition technique, no interference due to excipients was observed as shown from the results in Table $2 \& 3$.

The stability of IBU, FAM and tablet solutions in methanol has been studied by keeping one sample of each 
Table 1: Analytical parameters and validation results of the determination of ibuprofen and famotidine by the proposed methods

\begin{tabular}{|c|c|c|c|c|}
\hline \multirow{2}{*}{ Method parameter } & \multicolumn{2}{|c|}{ TLC method } & \multicolumn{2}{|c|}{ HPLC method } \\
\hline & Ibuprofen & Famotidine & Ibuprofen & Famotidine \\
\hline Wavelength (nm) & $265 \mathrm{~nm}$ & $265 \mathrm{~nm}$ & $265 \mathrm{~nm}$ & $265 \mathrm{~nm}$ \\
\hline Linearity range & $5-30 \mu \mathrm{g} /$ band & $0.3-1.3 \mu \mathrm{g} /$ band & $480-1120 \mu \mathrm{g} \mathrm{mL}^{-1}$ & $16-37 \mu \mathrm{g} \mathrm{mL}^{-1}$ \\
\hline Time of analysis (min/run) & \multicolumn{2}{|c|}{ - } & \multicolumn{2}{|c|}{ 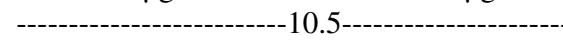 } \\
\hline \multicolumn{5}{|l|}{ Linearity } \\
\hline Intercept & 1283.7 & 1402.79 & -68.9979 & -60.8267 \\
\hline Slope & 263.52 & 8483.157 & 1.7118 & 49.619 \\
\hline Correlation coefficient (r) & 0.9923 & 0.9947 & 1 & 0.9999 \\
\hline \multicolumn{5}{|l|}{ Accuracy (Mean $\pm \%$ RSD) } \\
\hline Low conc. & $99.73 \pm 0.3$ & $98.67 \pm 1.15$ & $100.06 \pm 0.15$ & $99.71 \pm 0.50$ \\
\hline Medium conc. & $100.29 \pm 0.34$ & $99.58 \pm 0.72$ & $99.68 \pm 0.38$ & $100.88 \pm 0.85$ \\
\hline High conc. & $100.03 \pm 0.24$ & $99 \pm 1$ & $101.68 \pm 0.26$ & $100.34 \pm 0.63$ \\
\hline Specificity $^{\mathrm{a}}$ & $102.98 \pm 1.35$ & $100.4 \pm 0.96$ & $100.67 \pm 0.69$ & $100.77 \pm 0.62$ \\
\hline \multicolumn{5}{|l|}{ Precision } \\
\hline$( \pm \% \text { RSD })^{b}$ & \pm 0.37 & \pm 0.34 & \pm 0.03 & \pm 0.23 \\
\hline$( \pm \% \text { RSD })^{\mathrm{c}}$ & \pm 0.38 & \pm 0.50 & \pm 0.35 & \pm 0.27 \\
\hline Robustness & \pm 0.35 & \pm 0.87 & \pm 1.07 & \pm 1.38 \\
\hline $\mathrm{LOD}^{\mathrm{d}}$ & $1.5 \mu \mathrm{g} /$ band & $0.09 \mu \mathrm{g} / \mathrm{band}$ & $145 \mu \mathrm{g} \mathrm{mL}^{-1}$ & $4.7 \mu \mathrm{g} \mathrm{mL}{ }^{-1}$ \\
\hline$\overline{\mathrm{LOQ}^{\mathrm{d}}}$ & $5 \mu \mathrm{g} /$ band & $0.3 \mu \mathrm{g} / \mathrm{band}$ & $479 \mu \mathrm{g} \mathrm{mL}{ }^{-1}$ & $15.5 \mu \mathrm{g} \mathrm{mL}^{-1}$ \\
\hline
\end{tabular}

${ }^{a}$ Recovery of IBU and FAM in laboratory prepared mixtures containing degradation products

${ }^{\mathrm{b}}$ Intraday precision (average of 3 different concentrations of $/ 3$ replicate each $(\mathrm{n}=9)$ within the same day)

${ }^{\mathrm{c}}$ Interday precision (average of 3 different concentrations of / 3 replicate each $(\mathrm{n}=9)$ repeated on 3 successive days).

${ }^{\mathrm{d}}$ Calculated from equation $[\mathrm{LOD}=3.3(\mathrm{~S} . \mathrm{D} / \mathrm{S}), \mathrm{LOQ}=10(\mathrm{~S} . \mathrm{D} / \mathrm{S})$; where S.D is the residual standard deviation of the slope and $\mathrm{S}$ is the slope for TLC-densitometric and HPLC methods.

Table 2: Analysis of IBU and FAM in marketed formulations by TLC-densitometric method and application of standard addition technique

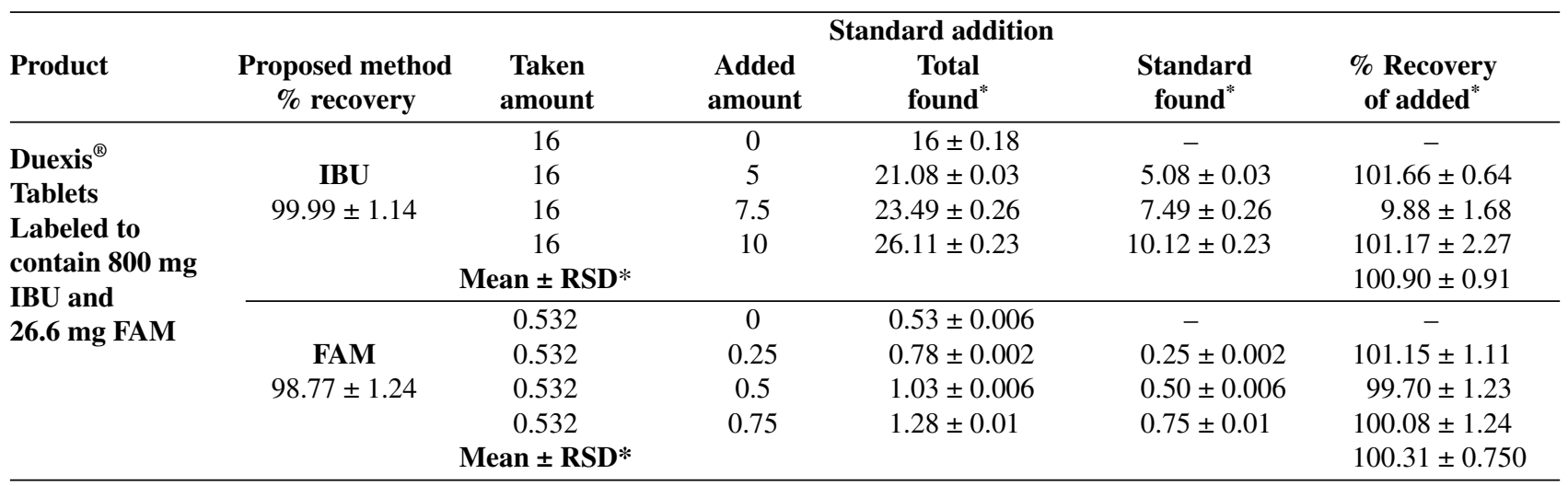

*Average of three determinations

drug in the refrigerator and another in a tightly capped volumetric flask, covered with aluminum foil and placed at ambient temperature. The samples were checked for assay in fourteen successive days of storage and compared with freshly prepared samples. The RSD values of assay were found to be below $2.0 \%$ which indicate that IBU, FAM and tablet are stable in the solutions for two weeks.

\section{Conclusion}

The proposed chromatographic methods enable simultaneous determination of ibuprofen, famotidine in presence of IBU impurity, acid and basic degradation products of famotidine, enabling good separation and resolution of the chromatographic peaks. This is the first reported methods for simultaneous quantitative analysis of this combination in presence of the degradation products and impurities. The method is suitable for qualitati- 
Table 3. Analysis of IBU and FAM in marketed formulations by HPLC method and application of standard addition technique

\begin{tabular}{|c|c|c|c|c|c|c|}
\hline \multirow[b]{2}{*}{ Product } & \multirow[b]{2}{*}{$\begin{array}{l}\text { Proposed method } \\
\text { \% recovery }\end{array}$} & \multicolumn{4}{|c|}{ Standard addition } & \multirow[b]{2}{*}{$\begin{array}{c}\% \text { Recovery } \\
\text { of added }\end{array}$} \\
\hline & & $\begin{array}{c}\text { Taken } \\
\text { amount }\end{array}$ & $\begin{array}{c}\text { Added } \\
\text { amount }\end{array}$ & $\begin{array}{c}\text { Total } \\
\text { found }^{*}\end{array}$ & $\begin{array}{c}\text { Standard } \\
\text { found* }\end{array}$ & \\
\hline \multirow{5}{*}{$\begin{array}{l}\text { Duexis }^{\circledR} \\
\text { Tablets } \\
\text { Labeled to } \\
\text { contain } 800 \mathrm{mg} \\
\text { IBU and }\end{array}$} & & 800 & - & $802.08 \pm 0.53$ & - & - \\
\hline & IBU & 800 & 120 & $922.62 \pm 1.23$ & $120.55 \pm 1.23$ & $100.46 \pm 1.02$ \\
\hline & $100.26 \pm 0.53$ & 800 & 240 & $1043.60 \pm 1.30$ & $241.52 \pm 1.30$ & $100.63 \pm 0.54$ \\
\hline & & Mean \pm RSD $^{\mathbf{a}}$ & & & & $100.55 \pm 0.780$ \\
\hline & & 26.6 & - & $26.59 \pm 0.12$ & - & - \\
\hline \multirow[t]{3}{*}{26.6 mg FAM } & FAM & 26.6 & 3.99 & $30.61 \pm 0.03$ & $4.01 \pm 0.03$ & $100.46 \pm 1.02$ \\
\hline & $99.98 \pm 0.12$ & 26.6 & 7.98 & $34.58 \pm 0.05$ & $7.98 \pm 0.05$ & $100.00 \pm 0.60$ \\
\hline & & Mean \pm RSD $^{\mathbf{a}}$ & & & & $100.24 \pm 0.640$ \\
\hline
\end{tabular}

*Average of three determinations a Average of two determinations

Table 4: Parameters required for system suitability testing of TLC-densitometric method

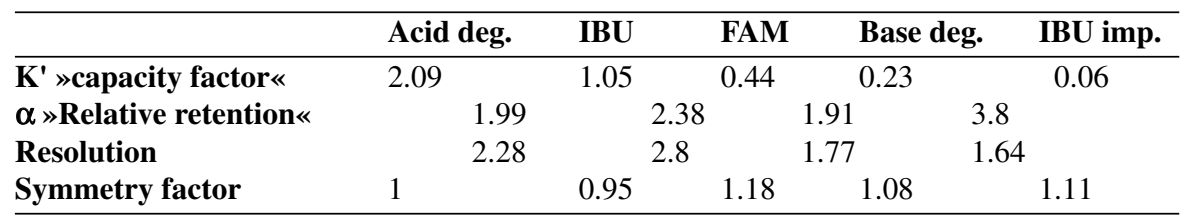

Table 5: Parameters required for system suitability testing of HPLC method

\begin{tabular}{|c|c|c|c|c|}
\hline \multirow{3}{*}{$\frac{\text { Parameter }}{\text { Resolution }}$} & \multicolumn{3}{|c|}{ Obtained value } & \multirow{2}{*}{$\begin{array}{c}\text { Reference } \\
\text { value }\end{array}$} \\
\hline & FAM & IBU impurity & IBU & \\
\hline & \multicolumn{2}{|c|}{29.5} & 3.66 & $\mathbf{R}>2$ \\
\hline $\bar{\alpha} »$ relative retention $«$ & \multicolumn{2}{|c|}{4.33} & 1.15 & $>1$ \\
\hline$\overline{\mathbf{K}^{\prime}}$ »capacity factor $«$ & 8.21 & 35.56 & 40.91 & $K^{\prime}>2$ \\
\hline $\mathbf{N} »$ column efficiency $«$ & 4220 & 12974 & 10596 & $\begin{array}{l}\text { The higher the value, } \\
\text { the increase in the } \\
\text { efficiency of separation }\end{array}$ \\
\hline HETP & $5.92 \times 10^{-3}$ & $1.93 \times 10^{-3}$ & $2.36 \times 10^{-3}$ & $\begin{array}{c}\text { The smaller } \\
\text { the value, the higher } \\
\text { the efficiency }\end{array}$ \\
\hline Tailing factor & 1.14 & 1.09 & 1.07 & $\begin{array}{l}T=1 \text { for typical } \\
\text { symmetric peak }\end{array}$ \\
\hline
\end{tabular}

ve and quantitative analysis of these pharmaceutical products. The results obtained are in a good agreement with the declared contents. Statistical analysis showed the method is accurate and precise. There was no interference from excipients in the tablets.

\section{References}

1. A. Patel and S. J. Rajput, Am. J. Pharm. Tech. Res.2012, 2, 593-601.

2. D. A. Shah, D. J. Suthar, C. D. Nagda, U. K. Chhalotiya and K. K. Bhatt, Arabian J. Chem.2012. http://dx.doi.org/10.1016/j.arabjc.2012.07.013
3. B. R. Kesur, D. V. R. Salunkhe and D. C. S. Magdum, Int. J. Pharm. Pharm. Sci.2012, 4, 271-274.

4. N. Narendra, G. S. Jeyabalan, K. Mukesh, K. Naresh and S. Gurpreet, Int. Res. J. Pharm.2012, 3, 277-280.

5. B. K. kumar, V. S. Thiruvengadarajan, T. S. Reddy and N. T. begum3, J. Pharm. Res.2012, 5, 4633-4634.

6. N. Nyola and G. S. Jeyabalan, J. Appl. Pharm. Sci.2012, 2, 79-83. http://dx.doi.org/10.7324/JAPS.2012.2512

7. D. P. Patel, R. R. Shah, A. P. Patel, R. S. Patel and M. H. Shukla, Pharma Sci. Monit.2012, 3, 2798-2811.

8. Y. R. Reddy, K. K. Kumar, M. Reddy and K. Mukkanti, Pharm. Methods. 2012, 3, 57-61. http://dx.doi.org/10.4103/2229-4708.103873 
9. D. A. Shah, D. J. Suthar, S. L. Baldania, U. K. Chhalotiya and K. K. Bhatt, ISRN Anal. Chem. 2012. http://dx.doi.org/10.5402/2012/674392

10. M. K. Joshi, L. L. Jha and R. K.S., Int. J. Instit. Pharm. Life Sci. 2012, 2, 24-29.

11. N. Dubey, D. K. Jain and S. Jadhawani, JPC - J. Planar Chromatogr.-Mod. TLC.2012, 25, 162-167.

12. S. SINGH, S. KUMAR, N. SHARDA and A. K. CHAKRABORTI, J. Pharm. Sci.2002, 91, 253-257.

13. A. I. Gasco-Lopez, R. Izquiredo-Hornilos and A. Jimenez, J. Pharm. Biomed. Anal.1999, 21, 143-149.

http://dx.doi.org/10.1016/S0731-7085(99)00127-2
14. I. E. W. Group, Stability Testing of New Drug Substances and products. ICH, Q1A (R2): International Conference on Harmonization, Geneva, Switzerland, 2003.

15. H. G. Brittain. Analytical Profiles of Drug Substances and Excipients, 2009, 115-151.

16. I. E. W. Group, Validation of Analytical Procedures: Methodology, ICH- Q2(R1): International Conference on Harmonization ( $\mathrm{ICH}$ ) of Technical Requirements for the Registration of Pharmaceuticals for Human Use., 2005.

\section{Povzetek}

Opisujemo dve validirani metodi za hkratno določitev ibuprofena in famotidina v prisotnosti nečistote ibuprofena (4-izobutilacetofenon) in/ali razgradnih produktov famotidina. Prva metoda je preprosta TLC metoda s separacijo na ploščah iz silikagela z mešanico etil acetat: metanol: amoniak $(9: 2: 1, v / v / v)$ kot mobilno fazo. Rf vrednosti so bile 0,40 za ibuprofen, 0,94 za 4-izobutilacetofenon, 0,66 za famotidin, 0,27 za kislinske razgradne produkte famotidina in 0,83 za bazične razgradne produkte famotidina. Druga metoda je bila HPLC na C18 koloni z mobilno fazo metanol: fosfatni pufer pH $3(80: 20, v / v)$. Retencijski časi so bili 2,2 min za famotidin, 9,9 min za ibuprofen in 8,6 min za 4-izobutilacetofenon. Obe metodi smo validirali po ICH smernicah in ju uporabili za določitev obeh učinkovin v čistem prašku ter v kombinirani farmacevtski obliki, pri čemer pomožna sredstva niso motila. 